Feminine Preoccupations: English at the Seven Sisters

Author(s): Mary Dockray-Miller

Source: Modern Language Studies, Vol. 27, No. 3/4 (Autumn - Winter, 1997), pp. 139-157

Published by: Modern Language Studies

Stable URL: http://www.jstor.org/stable/3195398

Accessed: 17-02-2017 01:32 UTC

JSTOR is a not-for-profit service that helps scholars, researchers, and students discover, use, and build upon a wide range of content in a trusted digital archive. We use information technology and tools to increase productivity and facilitate new forms of scholarship. For more information about JSTOR, please contact support@jstor.org.

Your use of the JSTOR archive indicates your acceptance of the Terms \& Conditions of Use, available at http://about.jstor.org/terms

Modern Language Studies is collaborating with JSTOR to digitize, preserve and extend access to Modern Language Studies 


\title{
Feminine Preoccupations: English at The Seven Sisters
}

\author{
MARY DOCKRAY-MILLER
}

History and Women's History. Basketball and Women's Basketball. The Norton Anthology of English Literature and The Norton Anthology of Literature by Women. Despite tremendous gains of women in the public sphere-as I write these words, Madeline Albright has just been named Secretary of State-our history and activities are still considered marked as "women's" and hence in some way unusual.

My own field of English Studies has been engaged in examining and discussing its own history for the past ten or fifteen years. More general books like Gerald Graff's Professing Literature and James Berlin's Rhetoric and Reality share the shelf with more specifically focused texts like Allen Frantzen's Desire for Origins, a history of Anglo-Saxon Studies in America. And yet the female component of this history has, by and large, been elided. With a thick black magic marker, I retitled Graff's book Men Professing Literature, for with the exception of a paragraph on Wellesley's Vida Scudder (84) and a reference to Wellesley's introductory literature class (102), women scholars and students are absent from the first parts of Graff's book (which deal with the nineteenth century and the early parts of the twentieth century). Graff's text, enlightening and important as it is, is actually a history of men. But "men's history" is not yet a section in our libraries.

Histories of English in American universities and colleges like Graff's and Berlin's tend to ignore or marginalize the field of women's higher education and to assume that women's colleges were simply smaller, female versions of the (mostly all male) universities like Harvard or Princeton usually cited as examples. The female institutions have been almost exclusively viewed as lagging a bit behind and struggling to keep up with their 
brothers. Such scholarship has failed to acknowledge aspects of women's English education-specifically at the Seven Sisters colleges before the First World War-that made the Sister colleges not only different from but also, in some critical ways, educationally superior to and more progressive than their male counterparts.

Rather than neglect the female side of our discipline's history, the English profession today can look to our female-and feminine-predecessors as we grapple with our discipline's conflicts in the 1990s. The departmental divides keep growing: between those who practice theory and those who don't; between those who "have to" teach composition and those who don't; between those who do more research than teaching and those who don't; between those who are tenured and tenurable and those who are not. The English departments of the pre-WWI Seven Sisters can provide guidance, in both philosophy and practice, as we struggle to acknowledge and close those gaps.

The Seven Sisters-Mount Holyoke, Smith, Wellesley, Radcliffe, Barnard, Vassar, and Bryn Mawr-were founded throughout the nineteenth century to provide education for women at the same level that Harvard, Yale, and Princeton provided it for men. Holyoke, the oldest of the sisters, opened as a seminary, not a college, in 1837; Barnard opened last in 1889. All seven offered courses of study similar, in some respects, to those of the Ivy League colleges, and all seven were decried by critics as radical and superfluous institutions that would (and of course did) encourage women to look beyond their prescribed station in life as wife and mother.

The sister colleges did differ from their male counterparts in overall philosophy and curriculum, and these differences were reflected in the English curriculum. There were, of course, obvious similarities between the Seven Sisters and the Ivy League, most notably the initial dedication to a classical education. The standard college curriculum in the first half of the nineteenth century included Greek, Latin, mathematics, history, logic, theology, natural science, and moral philosophy. ${ }^{1}$ Graff determines that women's colleges chose "classical courses of study" because of the "necessity to prove that women could undertake a serious course of study" (37). This imitation of the men's curriculum was most apparent at Barnard and Radcliffe, where women students paid Columbia or Harvard professors to duplicate the lectures they gave to the men.

1 While electives in English and modern languages may have been offered, most students could not take them; the study of Greek and Latin comprised up to half of a student's course work. Greek and Latin were supposedly literary courses, but actually focused on grammar, etymology, memorization, and philology (Graff 22 and 28). 
However, such imitation was not universal, as Graff and others like him assume. While the Seven Sister schools did offer the requisite Latin and Greek, the classical focus was not as sharp; the curriculum emphasis ranged from the arts (Smith and Wellesley) to the natural sciences (Vassar). Holyoke's elective system for juniors and seniors enabled a student to choose her own curricular focus in an educational environment that had "created free electives and new majors while the men's colleges were still clinging to the academic guidelines established by puritan clergymen" (Kendall 175). At Bryn Mawr, the classical curriculum was taught in an interdisciplinary manner that belied the Latin and Greek stuffiness described in the traditional histories of colleges: Bryn Mawr students went on archeological digs with professors whose stated faculty philosophy was that the students were junior colleagues (Vermeule 171) rather than vessels to be passively filled with the professor's knowledge. On the surface, Bryn Mawr may have looked like a little Yale; yet underneath, it was engaged in a unique and revolutionary intellectual dialogue between student and professor in the classical disciplines.

These larger philosophical and curricular differences were mirrored in the English departments of the Seven Sisters and their male counterparts until the First World War. English studies at men's colleges and universities were an outgrowth of the Greek and Latin curricula, emphasizing etymology, syntax, and rhetoric rather than examining the meanings of the works (Graff 39). An excellent example of such a curriculum is all-male Bowdoin College's 1880 "English Literature" class, required of all third term sophomores. Bowdoin students read Milton's Areopagitica, Bacon's Essays, and "Masterpieces of Burke and [Daniel] Webster" (1880-81 Catalogue 4). These nonfiction prose works, mostly essays or revised speeches about politics or philosophy, were studied as rhetorical examples. Bowdoin students also attended unspecified "Rhetoricals" every Wednesday afternoon through most of the 1880s and 1890s. Fiction and poetry written in English are not to be found.

The challenge for early English professors was to make English as difficult as Latin and Greek, and attention to philology ensured that the "mental discipline" provided by study of the classics would be found in English as well (Graff 70). Early English teachers taught rhetoric or composition classes; English literature was not originally part of the department's scope (Berlin 20). The typical writing curriculum included narration, description, exposition and argument (Berlin 55); professors emphasized theme writing and declamation, not literature (Graff 41).

All-male Haverford College is a typical example of this departmental structure. Until 1900, Haverford required "scripture and themes" from every student every term. In 1875, Haverford students took "English Literature" in their freshmen year, using Cleveland's Compendium and Hart's 
Rhetoric as their texts. While the Compendium does contain poetry and fiction, essays and memoirs comprise the bulk of its pages. The entry on Matthew Arnold is typical: it contains an essay on quality of translations of Homer, an essay on the relationship between Homer and Milton, and Arnold's poem "Desire," to which Cleveland adds a footnote that it could be called a prayer (Cleveland 758). While no syllabus from the 1875 English Literature class exists, the two text books and the content of the "reader" suggest that very little fiction or poetry was being read in the class. The titles of later courses bear out this suggestion: sophomore students took "The Philological Study of the English Language"; juniors had separate courses in Anglo-Saxon and Rhetoric; and seniors studied Philology, using Whitney's Science of Language as a text (1875 Catalogue 14-16). No courses focused on literature until 1890.

At most schools, when literature was in the classroom, it was simply used as an example for philological or structural analysis (Graff 41), as perhaps it was in Haverford's freshman class. What James Berlin, in Rhetoric and Reality, terms current-traditional rhetoric-an emphasis on the grammar, structure, and mechanics of a language that relates a pre-existing reality-was the dominant form of composition teaching throughout the nineteenth century (and the twentieth, for that matter); it was perfectly suited to the new middle-class business-oriented students pouring into the universities (Berlin 35).

The Seven Sisters subscribed to a great extent to this current-traditional philosophy of teaching writing. Barnard and Radcliffe offered the same current traditional courses and methods that Harvard and Columbia did; in Cambridge and New York City, men and women learned to write in basically the same way. Since "Harvard at this time led academic thought in the matter of teaching English" (Miller 40), both Barnard and Radcliffe women took daily theme courses like those offered at Harvard in the 1890s. Barnard women had to take two years of writing courses to graduate (Miller 67). Wellesley and Smith relied on current-traditional rhetoric as well; both had separate departments of English Language and English Literature well into the nineties (Smith's two departments finally merged in 1904) and at Smith, students not enrolled in English Language courses still were required to submit essays to the department "for criticism" (Seelye 124).

More current-traditional rhetoric was practiced across the mountain at Mount Holyoke, where students wrote every Saturday on a specific topic like nature or female education; the themes were then read aloud to the whole section (Cole 59). Students at Mount Holyoke took writing-oriented courses every year, from the seminary students in 1837 who studied "Logic and Rhetoric" to the four year students of 1860 enrolled in "Composition and Analysis of the English Language" to "Composition" taken by the 
students of 1879 (1837 Annual 8, 1860 Annual 18, 1879 Annual 21). Holyoke offered a spelling class to which the unfortunates who committed three spelling errors in a theme were banished; even penmanship was part of the composition classes (Cole 58). Similarly, at Bryn Mawr, students took two full years of writing from the day the college opened, with the addition of a required course in Aristotelian rhetoric in 1898 (1898 Program 107). Bryn Mawr had a variety of names for its writing course, like "Essay Work," "English Prose," and "Essay Section," but all these courses embraced current traditional rhetoric with emphasis on weekly or biweekly papers and mechanical correctness.

Vassar, too, followed the current traditional model. Students at Vassar took writing-intensive courses every semester for four years from 1865, the year the college opened, until 1875; the writing requirement gradually dwindled to one full-year freshmen writing course in 1905 (Catalogues). According to the 1875 catalogue, the mission of the Vassar English department was to

teach the student a good style of writing, reading, and speaking the English language, by assiduous exercise in the writing of themes and in silent readings and recitations; and lastly, to introduce her to English literature. (1875 Catalogue 19)

In all these instances, the Seven Sisters fall perfectly into traditional models of the ascendence of composition and of current traditional rhetoric in the early English department. Naturally, the women's colleges wanted to be considered equal to the Ivy League men's schools and offered similar courses with similar teaching methods. However, there were some important differences that point to a distinctly female teaching and learning experience.

The first dissimilarity is clear in the 1844 Mount Holyoke Seminary Annual, which reads, "all members of the school attend regularly to composition, reading, and calisthenics" (11). While historians depict the struggle to give English studies the legitimacy of Greek and Latin, at Mount Holyoke it was simply listed with the jumping jacks. That same year Mount Holyoke seniors read Paradise Lost in a course separate from the rhetoric (and calisthenics) course, although Graff and others contend that literature was not in the classroom yet except as a style-example. Haverford College had such a typical curriculum with no distinctly literary offerings. At Haverford, there were no electives for English Literature until 1891, and the philosophy of the 1875 "Rhetoric and English Literature" department focused on the effort "to stimulate thought, and train the mind to exactness and vigor." Knowledge of literature was preferred rather than required: "throughout the course, the study of the history and structure of the English Language, and of English and American Literature, will be encour- 
aged" (1875 Catalogue 31). While literature was "encouraged," it was certainly not generally available until 1891. In 1880, seniors took "Philology, etc." during the first half of the year and both Anglo-Saxon and English during the second half-the course description for "English" is "Philological study; themes" (1880 Catalogue 23). Thirty-six years earlier, Mount Holyoke students were reading Paradise Lost in a course by itself.

Another notable Seven Sisters practice is the private conference with the composition teacher at Vassar, now standard practice at most universities. These conferences were highlighted in the course descriptions every year, so it would seem they were exceptional and worth emphasizing. While Harvard's writing class in the late nineteenth century also included conferences (Berlin 38), twenty teachers were responsible for $2000 \mathrm{stu}-$ dents (Berlin 22), substantially reducing the possibility of intimacy and thoroughness. In contrast, the Vasssar conferences in the Rhetoric classes of the junior year included discussion of the student's work of the past two years as well as of the current year, thus providing a sense of development of the student's writing for both the teacher and the student (1890 Catalogue 38). While a student at Vassar endured the usual public recitation common to other schools, she also had the advantage of conferences that dispensed with the possibility of public humiliation. The catalogue description emphasized the private nature of these conferences: "The faults of each student are corrected in private interviews with her teacher" (1870 Catalogue 19). The conferences are also called "personal interviews" (1890 Catalogue 37). This could be considered a distinctly "feminine" educational method, choosing mutuality and nurturance over fear and hierarchy as incentive to learn.

At Vassar, then, faults were not exposed in public but discussed in private. In 1875, the catalogue reads: "The criticisms are minute, personal, and free, being made in private interviews between the teacher and the students individually" (1875 Catalogue 19). The word "free" is most interesting here; it assumes a rapport between the two parties, an ease of relationship that requires mutual respect. The word "free" is used again in the 1890 sophomore class description, wherein "free class-room discussion is made an important feature of the work" (1890 Catalogue 38). Again, the catalogue conveys a sense of mutuality in the classroom; the Vassar students were not perceived as passive recipients of a professor's lectured knowledge.

Bowdoin College provides a contrast to these descriptions; Bowdoin catalogues emphasize the number of hours spent in public declamation and "practical rhetoric." The first one-on-one conferences listed in the Bowdoin Catalogue, in 1900, do not emphasize privacy and freedom. In- 
stead, the description makes the "conference" seem more like a lecture where there is only one listener. The course is called "Themes" and I quote the description in full:

Four themes of not less than four hundred words each are required of all Juniors in each term. Subjects for themes are posted two weeks or more before the themes are due. Each theme is carefully read, the mistakes are marked, and a general criticism is written on the outside. The instructor then meets each student, hears him read his theme, points out the faults and merits of his writing, and suggests lines of profitable reading (1900 Catalogue 39).

This course description is an exercise in impersonality. The assignments are posted; there is no opportunity to ask questions when the assignment is initially given. The use of the passive voice (the theme is read, a criticism is written) adds to the aura of austerity. This is not a free and private exchange.

Most innovative of all was Bryn Mawr's writing class. Writing across the curriculum, all in vogue in the 1990s, was already in place at Bryn Mawr in the 1890s, when faculty members included writing instruction in a variety of non-English courses. Writing was a component of classes in the philosophy or archeology departments as well as English (LaBalme 161). Students were exposed to a variety of disciplines in such classes; they learned that writing is necessary outside of the English classroom. As colleges today struggle to implement "Writing Across the Curriculum" programs, a look to Bryn Mawr might be helpful-teachers made writing an integral part of an archaeology or Latin course, not something "added" to fulfill bureaucratic requirements. As such, these professors modelled the necessity of mastering this cross-disciplinary skill.

Bryn Mawr students in the nineteenth century did not graduate thinking that writing was done only in English class, or (even worse) that style and structure are important in writing done in English class but not anywhere else. How many professors of archeology today feel qualified to teach writing? How many even want to try? Perhaps such innovation was easier in institutions that were in themselves experiments; since university-level education for women was a new idea anyway, it may have been easier to break away from current traditional rhetoric in a women's college than a men's college.

Like other schools, the women's colleges were moving gradually to an emphasis on literature rather than composition. However, we must note an exception to this progression. While most colleges in the first decade of the twentieth century privileged literature and required only a full year writing course (Berlin 55-56), Mount Holyoke offered a complete under- 
graduate major in rhetoric. Holyoke was almost reactionary in its loyalty to its rhetoric courses; it kept up the practice of teaching rhetoric even after other schools had switched to a more literary focus.

Holyoke divided its department of English from its department of English Language and Literature. While the requirements in English (writing and rhetoric) gradually dwindled from four year-long courses in 1874 to two in 1904 to one in 1909 (Annuals), the number of courses available for majors increased to 20 by 1909 . These included a daily theme course (probably much like the ones at the Harvards of the 1870s); verse and drama composition; argument and journalism; and even a course for students who intended to become teachers of writing (1909 Annual 48-49). This is not to say that Mount Holyoke remained mired in the past, resistant to the philosophical changes in other English departments. However, Holyoke managed to continue to expand upon the collegiate tradition of writing and rhetoric while at the same time responding to the growth of the discipline of literature.

Just as the experimental nature of the women's college had enabled some of the sister colleges to choose a curricular focus that was not wholly classical, that same nature allowed the department at Mount Holyoke to continue its own tradition of teaching rhetoric without slavishly imitating the trends at the men's schools. As a result, the students at Mount Holyoke had a choice of majoring in literature or in rhetoric, a choice that was not available to the majority of male college students at the beginning of the twentieth century. ${ }^{2}$ This undergraduate major in rhetoric at Mount Holyoke is not even mentioned in Nan Johnson's Nineteenth Century Rhetoric in North America; although the catalogues from forty colleges are listed in her bibliography, with a geographical range from Massachusetts to Wyoming, there are no women's colleges included (301-303). Johnson, like other historians before her, assumes that women students were doing the same things in the same way that men students did. She misses an opportunity to explore diversification in the history of the field.

Literature was another subject where the women's colleges were decidedly divergent from the men's. While literature was regarded as extracurricular, too easy, or effeminate at the men's colleges through most of the nineteenth century, the women's colleges capitalized on that "effeminacy" and included literary study long before the men's colleges did, as it was considered an eminently suitable subject for young ladies to study.

2 For instance, by 1914 English majors at Bowdoin College took a variety of literature courses but there was no major in the department of rhetoric and oratory, which furnished the required writing and public speaking classes for freshmen as well as some electives (1914 Bulletin 66). 
This phenomenon was later parallelled in England, where extensive English studies appeared first at the new women's colleges and at adult-education establishments called Working Men's Colleges (Baldick 61). ${ }^{3}$ Middle-class men and upper-class women were initially the "consumers" of English studies in England while the men of Oxford and Cambridge continued to focus on Latin and Greek, for the most part scorning English literary study. Similarly, in the United States English literature was presumed to be a "natural" subject for the inferior feminine mind.

Previously, historians have asserted that literary study roughly in the form that we know it today-reading literature for its meaning, not to examine its philological roots-came into the mainstream in the late 1880s and 1890s, as those known as the "generalists" were struggling with philologists who wanted to make English as hard as Greek (Graff 67). However, the literature curriculum of the women's colleges has been ignored in the histories of literary study. Bryn Mawr required a year-long Survey of English Literature course in 1886, when courses like this "were rare or were complete innovations" (Meigs 41). Meanwhile, in 1875 at Vassar, sophomores were required to take a year-long course entitled "History of English Literature from Beowulf to Swift"; the course requirements state that students wrote "long critical essays" about the literature (1875 Catalogue 9). Even earlier, in 1863, Mount Holyoke required two years of the History of English Literature (1863 Annual 20) and one full year in 1859 (1859 Annual 12). The sexism that assumed that the aesthetic nature of literature was a natural female concern actually gave the Seven Sisters an edge and allowed them to develop serious critical literature courses before the supposedly more advanced men's schools did.

An aesthetic approach to literature investigates emotion and beautytwo concepts usually associated with "the feminine." Such an aesthetic, feminine approach to a poem, a play, or a novel emphasizes the text's emotional appeal, the development of its characters, and the beauty of its language. Female college students were using just this approach (something we in the English departments of the 1990s do as a matter of course, regardless of gender) in the 1860s and 1870s while their male counterparts were defining structure, deriving etymology, and discovering sources. Histories that ignore these course offerings and continue to insist that literature did not truly enter the mainstream curriculum until the end of the

3 The Cambridge women's colleges of Girton and Newnham were founded in 1869 and 1876, respectively; Lady Margaret Hall at Oxford was founded in 1878. It is important to note, however, that women were not accorded full status at Cambridge until 1948 and at Oxford until 1960, although women received Oxford degrees after 1920 (Brooke 319). Women's higher education is one field where the British have followed an American lead. 
nineteenth century present male intellectual history as human intellectual history, dismissing contradictory evidence from the female side as irrelevant or not worth investigating.

The ascendancy of literature over composition began with the application of philology to the English language. Since English had been considered too easy for a college subject (Graff 28) and a "second-class undertaking" (Berlin 20), it needed the scientific method of the philologists to give it legitimacy in the academy. The philologists used literature as a teaching tool for philological study, not as the focus of the course (Graff 68). What is currently the stuff of most undergraduate literature courses-reading literature and discussing its "meaning"-was largely relegated to the colleges' literary societies until the end of the nineteenth century. Colleges usually had a number of societies, dedicated to the study of "extracurricular modern subjects as science, English, history, music, art, literature, and contemporary fiction" (Graff 45). The Seven Sisters had their versions of these clubs-Philalethis at Vassar (Horowitz 63), Blackstick at Holyoke (Cole 305), the Barnard Bear (Miller 131) and the Lewis Carroll-inspired Reeling and Writhing at Bryn Mawr, whose publication was the first to publish Marianne Moore and HD (Meigs 234). However, the prevalence of literature classes at the women's schools shows that these clubs were not a substitute for literature classes as they were at the men's schools but a supplement to an already lively literary environment.

Most academics at the end of the nineteenth century felt that philology was too difficult or too manly for women to study. In an attack on philologists, Irving Babbitt accused them of "assert[ing] their manhood by philological research," showing the equation of philology with virility (Graff 88). In 1883, H.C.G. Brandt said that if literature was one of the "final touches to be put on young ladies in their seminaries," of course it would be too easy; he recommended that "English" should actually mean "the historical scientific study of the language, Beowulf and Chaucer" (Graff 73 ), which would presumably exclude the aforementioned young ladies. Jo McMurtry, who does include very short blurbs about three of the Seven Sisters in English Language, English Literature, states that a more belletristic approach to literature was considered appropriate for women:

Throughout much of the middle class, women were allowed the role of guardians of culture, in charge generally of the menfolk's rest and recreation with a dose of moral responsibility thrown in...English literature fit in as an appropriate pursuit. As a hobby it was quiet, it required no expensive equipment, it had moral overtones (if one excised the eighteenth-century novel, that is; many men refused to let their wives read Fielding), and it was intellectually accessible in that it did not require learning an ancient language. (11) 
Modern literature was just a "feminine preoccupation" (Graff 37 ) while philology (which usually required more than one ancient language) was not.

It is interesting to note the oppositions that come into play in such a discussion. Feminist theorists since Simone de Beauvoir have shown how masculinity defines itself through opposition to femininity. In nineteenthcentury English studies, "modern" is opposed to "classical" as the weaker and less desirable of the two; "feminine" and "accessible" become similarly opposed to "masculine" and "rigorous." The challenge and discipline required by classical philology allowed men to prove their etymological athleticism and oppose their intellectual feats to those of the weaker sex, who were not "in shape" to study philology. Modern teachers usually consider accessibility of curricular materials a desirable feature; the nineteenth-century masculine philologists disdained such womanish ease. Harvard professor Bliss Perry simply refused to teach philology to Radcliffe women (Kendall 154).

The exception to these oppositional pairs was Bryn Mawr, which challenged men's sole possession of the philological tradition, practicing philology with a classical vengeance that made Bryn Mawr as "rigorous" as any men's philology program of the day. Bryn Mawr's department was led by M. Carey Thomas, Dean and later President of the college. Thomas wrote her very traditional doctoral dissertation on Sir Gawain at Zurich; no American insitution except Johns Hopkins would accept a woman who wished to study graduate level philology. After accepting Thomas, Johns Hopkins prohibited her from attending classes with the male students, though she was welcome to pay the fees and take the exams (Meigs 70).

Thomas's traditional training is evident in the structure and requirements of the Bryn Mawr English department. In keeping with the fear that English was too easy, until WWI Bryn Mawr required an English major to be half of a double major, paired with a major in another language or in philosophy (1886-1917 Programs). In 1886 the English major took the four full year writing courses and the one full year literature survey required of every student; she also took "Historical Study of the English Language" for a year, focussing on Anglo-Saxon and early English texts; a semester of Shakespeare and Chaucer; and a semester of independent study (1886 Program 23-24).

The Bryn Mawr innovation of seminars with students as "junior colleagues" is especially important in the senior year of the English major, which by 1894 had been left completely open-ended as "a year of seminary-work (sic) and essay writing" agreed upon by the students and professors (1894 Program 68). The contrast between the "masculine" object of study and the more "feminine" approach to that study, wherein the stu- 
dent gives respected input to the choice of subject matter, exemplifies the pedagogical innovations developed by the Seven Sisters, although at Bryn Mawr the content of the curriculum was very traditional.

By the late 1890s, Bryn Mawr had relaxed its philological grasp to the point where one elective in Victorian poetry was offered (1899 Program 154), but Bryn Mawr's English program consistently remained more classical and more philologically oriented than any of its sisters'. The Bryn Mawr philosophy about English was that "there is...no modern literature, of which the study may not be fitly preceded, or supplemented, by the study of Latin and Greek" (Vermeule 162). Bryn Mawr's "unusual integration of literature, history, and archeology" (Vermeule 167) showed the overwhelmingly male philological establishment that women were more than capable of scientific examination of the language in a rigorous academic curriculum.

Graff contends, however, that throughout the 1890s and 1900s, the philological establishment was assimilating and compromising with the more humanist generalists, marking out turf boundaries, and confirming a tenuous peace between the two camps. This peace has led to an uneasy separation in the department. Throughout the twentieth century, the Introduction to Literature course has grown less philological and more humanistic. Graff argues that the philologists and their more modern counterparts, historical researchers, have basically ceded the undergraduate curriculum to the generalist/humanists; instead, they focus on graduate teaching, research, and publication (Graff 91-101). While historical research gradually replaced philological research, the privileging of research and publication over teaching began as early as the 1890s (Graff 62) and continues to the present day, when at most schools the number of publications is a more important factor in tenure decisions than teaching ability. ${ }^{4}$

Self examination and conscious choice seem to have led the Seven Sisters to some sort of resolution of this conflict between generalists and philologists. These resolutions, in philosophy and practice, could be instructive today as we in the profession seek to resolve our own conflicts, some of which I mentioned at the beginning of this essay. Before I turn to more contemporary issues, however, I wish to show that the distinctly feminine, experimental nature of the Seven Sisters English departments

4 This division in the departments of the late nineteenth century is the first of Graff's examples that work towards his overriding conclusion, that members of the English studies profession must "teach the conflict." The fragmentation between the researchers and the teachers is the most prominent of these conflicts in the first half of Graff's book. 
led those departments to a relatively harmonious resolution to the research/teaching conflict. Graff argues that at the end of the nineteenth century, bored students had no sense of the development of English literature, taught by a fragmented, philosophically divided department (Graff 177-188). If this was the case at Harvard and Columbia, then it was also true at Radcliffe and Barnard, which had the same curriculum. Indeed, all of Barnard's literature classes were elective (Miller 42), so the probability of a student having a fragmented vision of the history of English literature was high.

However, the other Seven Sisters had two distinct advantages over the men's colleges: they did not have graduate programs (except for Bryn Mawr, which had only one or two students a year) and they had the tradition of female aestheticism. While it would be naive and incorrect to state that the generalist/philologist divide did not exist at all in departments at women's colleges, examination of course offerings and departmental philosophy statements reveals that the divide and the fragmentation were much less severe. Wellesley, Smith, Mount Holyoke, and Vassar can provide an alternative history that presents solutions to this problem.

Wellesley and Smith solved the philology/generalist dispute by siding almost wholly with the generalist side, immersing themselves in the aestheticism that had always been considered a "feminine preoccupation." Wellesley English majors took philology and Anglo-Saxon as part of their course requirements, but non-majors took a general English literature survey that had a humanist, not scientific slant (Graff 102). The department philosophy was primarily aesthetic:

At a time when the study of literature threatened to become, almost universally, an exercise in the dry rot of philological terms, in the cataloguing of sources, or in the analyzing of literary forms, the department at Wellesley continued unswervingly to make use of philosophy, sources, and even art forms as a means to an end; that end was the interpretation of literary epochs, the illumination of intellectual and spiritual values in literary masterpieces, the revelation of the soul of the poet, dramatist, essayist, novelist. (Converse 138139)

This rejection of philology could occur because as females (the Wellesley English department consisted of four women in the late 1890s) in a maledominated profession, the Wellesley professors were most likely bound by neither of the expectations of male-defined professional success: research and publishing. A thorough survey of the institutional affiliations of the authors of the articles in the first twenty volumes of PMLA (1885- 
1905) reveals only one Wellesley affiliation; in 1904 Martha Hale Shackford published "A Definition of the Pastoral Idyll" (583-592). In contrast, six authors in the 1901 volume were affiliated with Harvard.

Perhaps in the larger academic community these women would be patronized as unpublished generalists who taught undergraduates (undergraduate women, for that matter); however, in their specific professional environment that was irrelevant. Patricia Palmieri has documented what she calls "the family culture of the faculty" at Wellesley at the turn of the century, wherein the all-female professorate developed an insular community of emotional and intellectual bonds (57-76). The Wellesley English department could be viewed as a few women teaching a few other women in a feminine aesthetic tradition; it could also be viewed as a viable alternative to the type of professional evaluation that undervalues teaching for the glory of publication and research. Obviously, some members of the male establishment respected Wellesley enough to visit it in the last quarter of the nineteenth century: John Greenleaf Whittier, Matthew Arnold, and Henry Wadsworth Longfellow all spoke at Wellesley (Kendall 121).

Smith, too, chose aestheticism in the research/humanist debate: it did not have a graduate program and it had been virtually ordered into a female aesthetic philosophy by Sophia Smith, its founder. In her will, she directed that "higher culture in the English language and literature be given in said college" (Hanscom 116); accordingly, the first circular advertising Smith read, "Probably more attention will be paid in this than in other colleges to the English Language and Literature, to criticism on the standard English authors, and to the writing of original essays" (Hanscom 118).

While it could be argued that Smith and Wellesley were ignoring, not teaching, the conflict, evidence suggests that they had examined the conflict and made a conscious decision. Bryn Mawr was available for female students interested in philology; there were probably not enough such students to fill English departments at all seven colleges anyway. Women teaching undergraduates at all-female colleges were most likely under much less, if any, pressure to publish than their male counterparts at the big universities. ${ }^{5}$ Smith and Wellesley-and Bryn Mawr too, for that mat-

5 Seven Sisters professors who published in PMLA were, by and large, male faculty practicing Germanic philology at Bryn Mawr: J. James Stuerzing (1885), Hermann Collitz (1887 and 1901), J. Douglas Bruce (1894 and 1898), Albert Haas (1902), Albert Schinz (1903), and Gordon Hall Gerould (1904). Gerould seems to have parleyed his publication record into a higher-status position; by the time he publishes again in PMLA, in 1905, he is affiliated with Princeton. The notable exception is Smith's Mary Augusta Scott, who published five times $(1895,1896,1898$, 1899, and 1901) on Elizabethan translations from Italian. 
ter-chose one side of the research/humanism divide and stuck with it, rather than trying to practice both and ending up with bored students and a fragmented department.

Like Smith and Wellesley, Vassar focussed on the aesthetic and humanist aspects of the tradition, although as a larger school it offered more philological electives. Interestingly enough, Vassar seems to have had more male faculty members as well, although none of the faculty published in PMLA's first twenty volumes. The course on Anglo-Saxon, almost undoubtedly philologically based, was always an available elective. Where philology was privileged in the men's schools, at Vassar it was optional. Seniors had a choice between two electives in 1880, three electives in 1890, and thirty-four electives (after a huge growth in the student body) in 1910; Anglo-Saxon was always available but never required. The objectives of the English department at Vassar continued to focus on proficiency of student writing, "general acquaintance with English literature," and a deeper knowledge of authors or periods selected by the student (1895 Catalogue 36). Freshmen and sophomores took required rhetoric and literature courses, with an "emphasis on the relation between the courses" (1890 Catalogue 37); the students wrote in rhetoric class about the literature they read in literature class. The 1890 Catalogue reads: "These two courses are correlated, and conducted so that one shall illustrate the other..." (37). While it is impossible to determine exactly what happened in the classroom over one hundred years ago, the Vassar catalogues indicate that the faculty collaborated to teach complementary classes that developed different skills while focusing on the same subject matter.

The complementary courses in rhetoric and literature at Vassar offer a plausible, immediately implementable solution to the composition/literature divide that so many colleges are facing today. This innovative and important departmental philosophy and course structure can serve as a model for English departments over one hundred years later. It calls for an emphasis on teaching rather than research, and requires collaboration between faculty members.

Such collaboration should be instructive for the English studies profession as we struggle with the conflicts I outlined in the beginning of this essay. Collaboration between composition and literature teachers is only one of a host of interdisciplinary and intradepartmental collaborative possibilities. Colleges could offer cooperative classes in postmodern literature and postmodern theory, in philosophy and literature, in history and literature, in art or art history and writing, in any academic subject and writing, in literature and philosophy - this list is limited only by the imaginations, intellects, and flexibility of the teachers and students involved. Such collaboration will cause administrative hassle, will entail more preparation time, and will detract from research opportunity. But such collaboration will 
also enrich the educations of the students and the teachers involved in the class, and make a start towards resolution of the conflicts that are currently leading us a down a road of division, of acrimony, and of reduced collegiality and intellectual exchange. Our own history shows us a way to begin to close the gaps.

In these curricular and pedagogical decisions, the Seven Sisters colleges point the way to explicitly defined choices about what kind of institutions they wanted to be. They set an example, perhaps an overly austere one, of departmental self definition. While many departments today seem to try to "cover" everything from writing to literature (all fields) to theory to multiculturalism to film and media studies, the Seven Sisters remind us of the value of doing a few things thoroughly. I am not suggesting we return to the sparse electives of the nineteenth century; I am suggesting some self-analysis and questions about each department's priorities. If teaching is important, why do prospective employers read an applicant's published (or unpublished) scholarly work instead of traveling to the applicant's insitution to see him or her teach? If research is important, why are junior faculty commonly innundated with high maintenance classes like composition and the introduction to literature? While each department will have vastly different answers to these questions, and vastly different choices and priorities, I argue that each department should ask those questions and make those choices.

When recent historians left women's education out of their histories of the English department, they merely repeated what male historians have done for generations: marginalized and ignored the female. Scholars have assumed that the Seven Sisters colleges simply followed along in the steps of their older Ivy League brothers. While superficially the similarities are definitely there, the differences must not be ignored. Criticized for providing education for women, the Seven Sisters set out to prove that they were just as good as the men's schools, but "just as good as" does not mean "the same." Bryn Mawr's department offered a curriculum more classical and more research-oriented than those at many of the men's schools, while the other sisters firmly supported the aesthetic tradition that had been their female heritage but is now claimed by the mainstream of the discipline. While Barnard and Radcliffe were less differentiated from their affiliated male schools than the other colleges, they shared the Seven Sisters advantages of small classes in intimate settings.

All of these differences point to English departments at Seven Sisters colleges before the First World War that were less fragmented, more coherent, and more personal than those at the men's schools they were supposedly imitating. Many of the educational practices that are valued in the university today -independent study, seminar classes, accessible materials, private student/teacher conferences, interdisciplinary team-teaching, 
and writing across the curriculum-were firmly in place at the women's colleges at the turn of the century. The women's colleges were less bound by tradition and the pressure of professional academia than their male counterparts, and thus were free to experiment with innovative curricula and methods.

The Seven Sisters were not by any means perfect educational institutions, but they did manage to copy or borrow what they wished from the traditional male educational establishment while adding experimental and "feminine" features that gave their English departments fewer conflicts and battlefields than the departments of the male schools which have received so much more critical and historical attention. Vassar, Barnard, Wellesley, Mount Holyoke, Radcliffe, Smith, and Bryn Mawr have all made significant contributions to the growth and diversity of the discipline. Those contributions can no longer be marginalized.

College and university English departments today face many divisions and conflicts similar to the splits experienced in the late nineteenth and early twentieth centuries. We grapple with the status of adjunct faculty, the place of theory in the classroom, the expansion of the canon, and the continuing deterioration of the writing skills of our students. Departments at the women's colleges actually implemented solutions to their problems, solutions that could provide us guidance as we try to solve ours; their examples of decisive choice in self-definition, of faculty-student interaction, of collegiality, collaboration, and personal attention can serve as guides for us as we come to the close of the twentieth century.

THE COllege of Advancing Studies at Boston College 


\section{Works Cited}

Annual Catalogue of Bowdoin College, for the Academical Year 1880-81. Brunswick: Bowdoin College, 1880.

Annual of Mount Holyoke College. South Hadley: Mount Holyoke College, 1894, 1904, 1909.

Annual of Mount Holyoke Seminary. South Hadley: Mount Holyoke Seminary, 1837, 1844, 1859, 1860, 1863, 1879.

Annual of Mount Holyoke Seminary and College. South Hadley: Mount Holyoke Seminary and College, 1888.

Baldick, Chris. The Social Mission of English Criticism. Oxford: Clarendon, 1983.

Berlin, James. Rhetoric and Reality: Writing Instruction in American Colleges 1900-1985. Carbondale: Southern Illinois UP, 1987.

Bowdoin College Bulletin, 1914-15. Brunswick: Bowdoin College, 1914.

Brooke, Christopher, and Roger Highfield. Oxford and Cambridge. Cambridge: Cambridge UP, 1988.

Bryn Mawr College Program. Philadelphia: Sherman, 1886, 1894, 1898, 1899.

Catalogue of Bowdoin College and the Medical School of Maine. Brunswick: Bowdoin College, 1900.

Cleveland, Charles Dexter, ed. English Literature of the Nineteenth Century: On the Plan of the Author's Compendium of Literature. New York: A.S. Barnes, 1866.

Cole, Arthur C. A Hundred Years of Mount Holyoke College. New Haven: Yale UP, 1940

Converse, Florence. The Story of Wellesley. Boston: Little, Brown, and Co., 1915.

Graff, Gerald. Professing Literature: An Institutional History. Chicago: U of Chicago P, 1987.

Hanscom, Elizabeth D. and Helen French Greene. Sophia Smith and the Beginnings of Smith College. Northhampton: Smith College, 1926.

Haverford College Catalogue. Haverford: Haverford College, 1875, 1880. 
Horowitz, Helen Lefkowitz. Alma Mater: Design and Experience in the Women's Colleges from their 19th Century Beginnings to the 1930s. New York: Knopf, 1984.

Johnson, Nan. Nineteenth Century Rhetoric in North America. Carbondale: Southern Illinois UP, 1991.

Kendall, Elaine. Peculiar Institutions: An Informal History of the Seven Sisters Colleges. New York: G.P. Putnam's Sons, 1975.

LaBalme, Patricia Hochschild, ed. A Century Recalled: Essays in Honor of Bryn Mawr College. Bryn Mawr: Bryn Mawr College Library, 1987.

McMurty, Jo. English Literature, English Language: The Creation of an Academic Discipline. Connecticut: Archon Books, 1985.

Meigs, Cornelia. What Makes a College?: A History of Bryn Mawr. New York: MacMillan, 1956.

Miller, Alice D. Barnard College: The First 50 Years. New York: Columbia UP, 1939.

Neal, Heather, and Judith Hammerschmidt. A Preposterous Extravagance. Bryn Mawr: The Baldwin School, 1988.

Palmieri, Patricia Ann. In Adamless Eden: The Community of Women Faculty at Wellesley. New Haven: Yale UP, 1995.

Publications of the Modern Language Association, vols 1-20. Baltimore, 18851905.

Seelye, L. Clark. The Early History of Smith College. Boston: Houghton Mifflin, 1923.

Vassar College Catalogue. Poughkeepsie: Vassar College, 1865, 1870, 1875, 1890, 1895, 1905.

Vermeule, Emily Townsend. "The Key to the Fields: The Classics at Bryn Mawr." LaBalme 161-172. 